\title{
Origins of Addiction Predictably Embedded in Childhood Trauma: A Neurobiological Review
}

\author{
Susie Wiet \\ General, Child and Adolescent Psychiatrist, Addiction Medicine, Holistic Treament for Psychiatry Trauma Addiction, \\ University of Utah-Adjunct Volunteer Faculty, Salt Lake City, UT, USA
}

\begin{abstract}
The seeds of addiction are typically sown years prior to the onset of addictive substance use or engagement in addictive behaviors, due to the priming of the reward pathway (RewP) by alterations in the mechanism of stress-signaling from the hypothalamic-pituitary-adrenal axis (HPA) and related pathways. Excessive stress from a single-event and/or cumulative life experiences during childhood, such as those documented in the Adverse Childhood Experiences Study, is translated into neurobiological toxicity that alters the set-point of the HPA axis and limbic system homeostasis [suggested new term: regulation pathway (RegP)]. The resultant alteration of the RegP not only increases the risk for psychiatric and physical illness, but also that for early onset and chronic addictions by dysregulating the RewP. This paper reviews the interface of these symbiotic pathways that result in the phenotypic pathology of emotional dysregulation, cognitive impairment, and compulsive behaviors, as well as morbidity and shorter life expectancy when dysregulated by chronic stress.
\end{abstract}

Key Words: Childhood trauma; Reward pathway; Addiction.

Received: October 2, 2016 / Revision: November 7, 2016 / Accepted: November 8, 2016

Address for correspondence: Susie Wiet, General, Child and Adolescent Psychiatrist, Addiction Medicine, Holistic Treament for Psychiatry Trauma Addiction, Univeristy of Utah-Adjunct Volunteer Faculty, Salt Lake City, UT 84102, USA

Tel: +1-801-915-3698, Fax: +1-844-838-8100, E-mail: swiet@susiewietmd.com

\section{INTRODUCTION}

\section{When does addiction begin?}

The origin of addiction begins much earlier than when diagnostic criteria are met for a substance use disorder (SUD) in the Diagnostic and Statistical Manual of Mental Disorders, 5th edition (DSM-5) (see Box). The story of addiction also begins much earlier than the definition (short version) of the American Society for Addiction Medicine: a primary, chronic disease of brain reward, motivation, memory and related circuitry. Dysfunction in these circuits leads to characteristic biological, psychological, social and spiritual manifestations $\cdots$ reflected in an individual pathologically pursuing reward and/or relief by substance use and other behaviors. ${ }^{1}$

DSM-5 revised the categories and criteria for a diagnosis of a SUD; the nine identified SUDs are further qualified as mild, moderate, severe; the qualification is based on 11 symptoms of impairment that stratify across four categories of function: 1) behavioral control, 2) social/emotional expression, 3) cognitive distortions, and 4) tolerance/

This is an Open Access article distributed under the terms of the Creative Commons Attribution Non-Commercial License (http://creativecommons.org/licenses/by-nc/3.0) which permits unrestricted non-commercial use, distribution, and reproduction in any medium, provided the original work is properly cited. withdrawal. These categories correlate with brain nuclei that are primary components of addiction pathways.

The origin of addiction, particularly moderate and severe forms, begins most often during childhood, before any addictive substance is used or addictive behavior is stimulated. Addiction seemingly originates from exposure of normal neuropathways to toxic levels of normal neural substrates that regulate stress. ${ }^{2)}$ The aberration in this system can be induced by a single experience and/or an accumulation of life experiences, such as childhood trauma $(\mathrm{CT})^{*}$, and that are perceived as overwhelmingly life-threatening, frightening, and/or inescapable [criteria for post-traumatic stress disorder (PTSD)] and that are translated into neurobiological toxicity, causing harm to the pathway intended to manage stress. When left unresolved, and especially when occurring during neurodevelopment (e.g. childhood through age 18), the altered function leads to sustained imbalance causing downstream effect to related pathways ( ${ }^{*}$ for the purpose of this paper, CT will be inclusive of all forms of abuse, trauma, neglect, and/or violence.).

Biological mediators of stress on physical health were minimally understood in the 1990s, although cardiac research had identified allostatic load as an independent risk factor for myocardial infarction (MI). ${ }^{3)}$ Similarly, depression was 
identified as a risk factor for poor outcome post-MI. ${ }^{4)}$ The mechanism that linked MI risks and outcomes remained perplexing; the variables (e.g. allostatic load and depression) reached beyond conventionally known risk factors at the time (e.g. smoking, hyperlipidemia, obesity, etc.). Rather, a more ubiquitous influence was yet to be discovered that linked allostatic load, depression, cardiovascular disease, addiction, and numerous other poor health outcomes.

The first findings emerged from the adverse childhood experiences (ACE) Study, also in the 1990s. The ACE Study culminated findings by Drs. Felitti and Anda, who independently identified strong correlations between chronic diseases and early-childhood adversities. ${ }^{5,6)}$ Among the list of diseases linked to the original ten ACE Study questions are autoimmune, ${ }^{7)}$ cardiovascular disease, ${ }^{8)}$ diabetes, ${ }^{9)}$ obesity, ${ }^{10)}$ and cancer. ${ }^{11)}$ Among the list of mental-health disorders linked to the same ten ACE-Study questions are chronic depression, ${ }^{12)}$ anxiety, ${ }^{13)}$ and addiction. ${ }^{6,14)}$

This paper reviews: 1) the key interfaces of these pathways in normal conditions and 2) the resulting pathology from neurotoxic doses of endocrine substrates that lead to a functional collapse or enmeshment of these pathways. The blended, imbalanced pathways lead to predictable phenotypic behavioral pathology including emotional dysregulation, cognitive impairment, compulsive behavioral reactivity, which correlate with DSM-5 symptom clusters.

As these pathways converge in dysfunction (and remain untreated), the long-term effects predictably result in chronic illness, progressive psychopathology, and correlate with early death, which are well-documented and independent outcomes in both addiction and toxic stress literature. ${ }^{15,16}$

\section{PATHWAYS}

\section{Homeostasis and regulation pathway}

The limbic system (LS) is the emotional engine that integrates with the corpus through the hypothalamus (HYP). The LS processes emotional understanding about internal and external influences, which can be fully conscious, subconscious, or unconscious. The LS has efferent and afferent projections with the autonomic nervous system (ANS) via the HYP. The HYP is the somatic-sensory clearinghouse of LS and integrates autonomic function into emotional processing, memory, and cognitive understanding. ${ }^{17}$ The HYP rallies to meet the daily demands of stress that are communicated through the hypothalamic-pituitary-adrenal axis (HPA).

The HPA originates in the forebrain of the central nervous system (CNS) and involves efferent and afferent communication with the corpus via the ANS, including both the parasympathetic and sympathetic nervous systems (respectively). Stress activates pro-inflammatory markers, such as corticotropicreleasing-hormone (CRH) and/or vasopressin (VSP). CRH triggers secretion of the pro-hormone, pro-opioid-melanocortin (POMC), from the HYP and which cleaves into betaendorphin ( $\beta$-END) and adrenocorticotropin-hormone (ACTH).

$\beta$-END modulates inflammation and pain in both the CNS and the ANS. $\beta$-END effects the CNS by stimulating several structures that are densely packed with opiate receptors, including the periaqueductal gray area and the amygdala (AMY) that are implicated in pain control, particularly during inflammatory states. $\beta$-END dampens perception of pain in the CNS by inhibiting gamma-Aminobutyric acid (GABA) release, which effectively results in release of dopamine (DA). ${ }^{18)}$ Interestingly, in the periphery, additional $\beta$-END production is stimulated in lymphocytes by $\mathrm{CRH}$ and arginine vasopressin (AVP), as well as pro-inflammatory cytokine interleukin (IL)-1, ${ }^{19,20)}$ which results in important down-regulation or inhibitory function of both B-cell and T-cell lines. Hence, the regulation pathway (RegP) simultaneously influences the balance of pain perception and inflammation in both the CNS and periphery, which has important implications for maintenance of health.

POMC-induced ACTH secretion occurs simultaneously with $\beta$-END but through the anterior pituitary. ACTH is synergistic when VSP is present, ${ }^{21)}$ and ACTH will-alone or with VSP-stimulate nearly instantaneous secretion of cortisol (CORT) from the adrenal cortex. A negative feedback loop will inhibit CRH secretion when CORT stimulates glucocorticoid receptors densely located in the HYP and peppered throughout the RegP. This pathway targets reduction of neuroendocrine effects of stress by decreasing the acute pro-inflammatory state and restoring homeostasis, which is fundamental to health and survival. ${ }^{22)}$ The HPA originates in the HYP; therefore, it has an integral relationship with the LS and influences procurement of mental and physical health by modulatory action on the ANS.

The LS-HPA is the emotional-physical engine in all mammals that integrates input from primitive regions of the brain through the cortices (Fig. 1). It influences how we interpret and respond to emotions that are stimulated by the internal and external environments, and for humans, it also integrates automatic thoughts and judgments. It is a sophisticated pathway that simultaneously synthesizes tremendous input from internal and external experiences. Collectively, the LS-HPA will be referred to as the regulatory pathway (RegP) for the purpose of this review. The RegP is one of the few areas of the CNS that begins to fully function in utero, and its purpose is to efficiently process strong emotions while maintaining ANS homeostasis and health. ${ }^{23)}$ The HPA is an endocrine cascade, 
which plays a central role as governess over other endocrine cascades ${ }^{24)}$ neurotransmitters, ${ }^{25)}$ and immune-modulators. ${ }^{26)}$ The HPA's primary function is to respond to perturbations of metabolic equilibrium, return the ANS to homeostasis, and promote health and wellness.

\begin{tabular}{|c|c|c|}
\hline Reward Pathway & STRUCTURE & Regulation Pathway \\
\hline $\begin{array}{l}\text { Evaluates affective value of } \\
\text { stimulus }\end{array}$ & Cerebral Cortex & Higher-ordered thinking \\
\hline Avoid consequences & Cingulate Gyrus & $\begin{array}{r}\text { Cognitive flexibility, social } \\
\text { adaptation }\end{array}$ \\
\hline Links reward with context & $\begin{array}{c}\text { Septal Area } \\
\text { annex to corpus callosum }\end{array}$ & $\begin{array}{r}\text { Inhibition of fear, enhancement } \\
\text { of pleasure }\end{array}$ \\
\hline Positive reinforcement of behavior & $\begin{array}{l}\text { Ventral Pallidum } \\
\text { Forebrain } \\
\text { Substantia Innominata }\end{array}$ & \\
\hline Emotional experience of behavior & $\begin{array}{c}\text { Extended Amygdala } \\
\text { Temporal Lobe } \\
\text { Corticomedial } \\
\text { Basolateral } \\
\text { Bed Nucleus Stria Terminalis }\end{array}$ & $\begin{array}{l}\text { Emotional tone, fight-or-flight, } \\
\text { sociability }\end{array}$ \\
\hline \multirow[t]{2}{*}{ Learning and memory } & $\begin{array}{l}\text { Hippocampus } \\
\text { Temporal Lobe }\end{array}$ & $\begin{array}{r}\text { Short-term into long-term memory, } \\
\text { navigation }\end{array}$ \\
\hline & $\begin{array}{l}\text { Olfactory Cortex } \\
\text { Temporal Lobe (Uncus) }\end{array}$ & $\begin{array}{r}\text { Identify odors, reception, } \\
\text { awareness }\end{array}$ \\
\hline $\begin{array}{l}\text { Motivation and action, Reward } \\
\text { perception }\end{array}$ & $\begin{array}{c}\text { Striatum } \\
\text { Forebrain } \\
\text { Nucleus Accumbens } \\
\text { (Ventral Striatum }=\text { core + olfactory } \\
\text { tuburcle): shell, core } \\
\text { Dorsal Striatum (Globus pallidus + } \\
\text { Putamen) }\end{array}$ & Cognitive processing of aversion \\
\hline \multirow[t]{2}{*}{ Maintain homeostasis } & $\begin{array}{c}\text { Hypothalamus } \\
\text { Forebrain } \\
\text { Mammillary Bodies } \\
\text { Ventromedial Nucleus } \\
\text { Lateral Hypothalamic Area }\end{array}$ & Maintain homeostasis \\
\hline & $\begin{array}{l}\text { Olfactory Bulb } \\
\text { Forebrain }\end{array}$ & \\
\hline $\begin{array}{l}\text { Modulates mesolimbic system } \\
\text { (feeding, energy, arousal, and } \\
\text { metabolism) }\end{array}$ & $\begin{array}{l}\text { Thalamus } \\
\text { Forebrain }\end{array}$ & $\begin{array}{r}\text { Motor control, sensory stimuli } \\
\text { synthesis }\end{array}$ \\
\hline $\begin{array}{l}\text { Positive reinforcement } \\
\text { for survival }\end{array}$ & $\begin{array}{l}\text { Ventral Tegmental Area } \\
\text { Midbrain }\end{array}$ & Positive reinforcement for survival \\
\hline \multirow[t]{5}{*}{ Primitive stress detection } & $\begin{array}{c}\text { Nucleus Incertus } \\
\text { Pre-pontine Hindbrain } \\
\text { (midline periventricular central gray) }\end{array}$ & $\begin{array}{r}\text { Primitive stress detection, regulates } \\
\text { hypothalamic tone }\end{array}$ \\
\hline & $\begin{array}{l}\text { Pituitary Gland } \\
\text { Brain-Base }\end{array}$ & Regulate endocrine system \\
\hline & Brain-Corpus Distinction & \\
\hline & $\begin{array}{c}\text { Autonomic Nervous System } \\
\text { Sympathetic } \\
\text { Parasympathetic }\end{array}$ & \\
\hline & Adrenal Cortex & $\begin{array}{r}\text { Mobilizes substrates needed by the } \\
\text { body during stress }\end{array}$ \\
\hline
\end{tabular}

Fig. 1. Reward pathways and regulation pathways. Copyright ( ) Susie Wiet, MD 2016.
Survival and reward pathway

The reward pathway (RewP) has evolved in all mammals, and the contributing structures and relevant functions are well-documented. ${ }^{27)}$ This exquisite neurocircuitry evolved to ensure survival of the species, simply by releasing DA from the nucleus accumbens (NAcc), located in the frontal stria- 
Table 1. Reward pathway

\begin{tabular}{|c|c|c|c|}
\hline Pathway & Structures & Reward behavior & Addictive behavior \\
\hline Ascending (mesolimbic) & $\begin{array}{l}\text { Ventral tegmental area to } \\
\text { nucleus accumbens (shell, core) }\end{array}$ & Desire to repeat a behavior & Craving a drug or behavior \\
\hline Descending & $\begin{array}{l}\text { Extended amygdala to ventral } \\
\text { tegmental area }\end{array}$ & $\begin{array}{c}\text { Emotional intensity linked to } \\
\text { a behavior or experience }\end{array}$ & $\begin{array}{l}\text { Intoxication linked to a drug, } \\
\text { behavior, or experience }\end{array}$ \\
\hline Further ascending & $\begin{array}{l}\text { Core nucleus accumbens to } \\
\text { ventral pallidum } \\
\text { Shell nucleus accumbens to } \\
\text { prefrontal cortex to core } \\
\text { nucleus accumbens }\end{array}$ & $\begin{array}{l}\text { Positive reinforcement of } \\
\text { behavior }\end{array}$ & $\begin{array}{c}\text { Negative reinforcement of a } \\
\text { drug-associated behavior }\end{array}$ \\
\hline Interneuron & Ventral tegmental area & $\begin{array}{l}\text { Reinforcing positive } \\
\text { reinforcement }\end{array}$ & $\begin{array}{l}\text { Reinforcement of negative } \\
\text { reinforcement of drug use }\end{array}$ \\
\hline
\end{tabular}

tum. A simplified summary of these pathways includes: 1) ascending pathway [mesolimbic: ventral tegmental area (VTA) to the NAcc, DA dominance]: the classical system referenced in reward/addiction that results in wanting to repeat a behavior (to ensure survival), 2) descending pathway [bed nucleus of the stria terminalis (BNST) to the VTA, opioid dominance]: producing the intensity of an experience, 3) further-ascending [NAcc to ventral pallidum, GABA and glutamate (GLU) dominance]: resulting in reinforcement of behavior, and 4) interneuron (VTA, opioid dominant): additional positive reinforcement (Table 1). In normal conditions, these circuits enhance learning and promote survival.

Reward+predictive cue $\rightarrow$ strong reinforcement

Expanded efferent and afferent feeds of the RewP integrate emotions, thoughts, and behaviors, which are similar functions of the RegP (Fig. 1). A simplified view of the RewP function includes: 1 ) the extended-amygdala (EAm), which is pertinent for reward perception ${ }^{28)}$ and integrating ever-changing emotional states. ${ }^{29)}$ The EAm influences both the s-NAcc (shell) and the BNST [via CRH, dynorphin (DYN), and norepinephrine (NE)], as well as the HYP and spinal column through the ANS, 2) the striatum [STR, ventral (v-) and dorsal (d-)] and thalamus (THAL) mediate energy and arousal states. 3) the prefrontal cortex (PFC), vSTR, and hippocampus (HIPP) (implicated in memory) are pertinent for 'cueing, ${ }^{30)}$ that influences repetition or avoidance of behavior; ${ }^{31)}$ This can be simplified by looking at survival as the integration of three fundamental aspects of the human condition: emotions, thoughts, and behaviors.

\section{IMPACT}

\section{Childhood trauma and the regulatory and reward pathways}

Addiction is well-known to be associated with the diagnosis of PTSD and has been well-documented in studies of vet- erans. ${ }^{32)}$ Many veterans have life-long struggles with addiction that resulted as compensatory survival responses to the unbearable symptoms of PTSD. In the late 1990s, PTSD literature described CT as a highly correlative risk factor for onset of combat-related PTSD, ${ }^{33,34)}$ versus the onset of combat-related-only PTSD. Studies also support onset of addiction as a significant predictor of a history of CT when combat-related PTSD has been diagnosed. ${ }^{35,36)}$

Childhood trauma+combat-exposure $\rightarrow$ PTSD

$\longrightarrow$ addiction

These studies suggest delayed onset of addiction that is triggered by additional insult to the RegP leading to PTSD, that perhaps overloaded remaining resiliency traits that had previously defended the RewP. Readily available addictive substances and/or environmental cueing (other veterans using) were likely contributing factors to initiation of addictive substances.

Etiology of addiction due to CT is the confluence of a dysregulated RegP, which gives rise to pathology in the RewP. ${ }^{37)}$ CT-related stress upregulates normal function of the RegP, including neuroendocrine modulators associated with the HPA. The RegP attempts to quell acute spikes of stress, while managing an overall upregulated pathway. Higher-ordered thought processes are neurochemically dissociated from the overrun LS-HPA circuitry. Clinically, the LS hijacks emotional processing of stress disallowing cognitive awareness, perhaps as an attempt to protect for survival.

The pathology caused by CT is in part caused by chronic bombardment of $\mathrm{CRH}$, which is ubiquitously released throughout the CNS and has profound downstream effects on RegP and major endocrine cascades. ${ }^{38,39)}$ Though an admirable attempt, these changes result in a sustained pro-inflammatory state mediated by chronic release of $\mathrm{CRH}$, which is detrimental to health ${ }^{40)}$ and is implicated in many chronic illnesses. This is not unlike adaptation in other organ systems. For example, the pancreas will adapt to manage an acute elevation of glucose by increasing insulin production that will 
return circulating glucose to a homeostatic level. However, if glucose is chronically elevated, the pancreas will eventually be unable to keep up with insulin production to meet the demand. Insulin resistance then ensues and causes significant downstream effects on the function of other organs and systems. Repetitious, toxic stress taxes the HPA resulting in metabolic disequilibrium and decreased immune function. Indeed, in lieu of HPA dysregulation, chronic illnesses arise from pro-inflammatory states that stress unique genomic vulnerabilities that may otherwise lie dormant. ${ }^{41)}$

\begin{tabular}{|c|c|c|c|c|}
\hline ADDICTION & $\begin{array}{l}\text { Reward } \\
\text { Pathway }\end{array}$ & STRUCTURE & $\begin{array}{r}\begin{array}{r}\text { Regulation } \\
\text { Pathway }\end{array} \\
\end{array}$ & TOXIC STRESS \\
\hline \multirow[t]{4}{*}{ Loss of empathy } & $\begin{array}{l}\text { Evaluates } \\
\text { affective } \\
\text { value of stimulus }\end{array}$ & Cerebral Cortex & $\begin{array}{r}\text { Higher-ordered } \\
\text { thinking }\end{array}$ & $\begin{array}{r}\text { Irrational behavioral } \\
\text { responses }\end{array}$ \\
\hline & & Cingulate Gyrus & & \\
\hline & & Septal Area & & \\
\hline & & Ventral Pallidum & & \\
\hline \multirow[t]{3}{*}{$\begin{array}{l}\text { Dysphoria } \\
\text { (withdrawal), } \\
\text { hyper-excitability, } \\
\text { depression, stress, } \\
\text { isolation }\end{array}$} & & $\begin{array}{c}\text { Extended Amygdala } \\
\text { Temporal Lobe } \\
\text { Bed Nucleus Stria } \\
\text { Terminalis }\end{array}$ & $\begin{array}{r}\text { Emotional tone, } \\
\text { fight-or-flight, } \\
\text { sociability }\end{array}$ & $\begin{array}{r}\text { Dysphoria, anger- } \\
\text { reactivity, fear, } \\
\text { hypervigilance, anxiety }\end{array}$ \\
\hline & & $\begin{array}{l}\text { Hippocampus } \\
\text { Temporal Lobe }\end{array}$ & & \\
\hline & & Olfactory Cortex & & \\
\hline $\begin{array}{l}\text { Binge and } \\
\text { intoxication, } \\
\text { hedonic tone }\end{array}$ & $\begin{array}{l}\text { motivation } \\
\text { and } \\
\text { action } \\
\text { reward } \\
\text { perception }\end{array}$ & $\begin{array}{c}\text { Striatum } \\
\text { Forebrain } \\
\text { Nucleus Accumbens: } \\
\text { shell, core }\end{array}$ & $\begin{array}{l}\text { Cognitive } \\
\text { processing } \\
\text { of aversion }\end{array}$ & $\begin{array}{r}\text { Automated } \\
\text { (destructive) } \\
\text { behaviors, anhedonia }\end{array}$ \\
\hline \multirow[t]{3}{*}{$\begin{array}{l}\text { Impaired immune, } \\
\text { gastrointestinal, } \\
\text { endocrine and } \\
\text { cardiovascular, } \\
\text { CNS and ANS } \\
\text { function }\end{array}$} & $\begin{array}{l}\text { Maintain } \\
\text { homeostasis }\end{array}$ & $\begin{array}{c}\text { Hypothalamus } \\
\text { Forebrain } \\
\text { Other nuclei of the } \\
\text { hypothalamus } \\
\text { Paraventricular Nucleus }\end{array}$ & & $\begin{array}{r}\text { Impaired immune, } \\
\text { gastrointestinal, } \\
\text { endocrine and } \\
\text { cardiovascular, central } \\
\text { nervous system and } \\
\text { autonomic nervous } \\
\text { system function }\end{array}$ \\
\hline & & $\begin{array}{l}\text { Olfactory Bulb } \\
\text { Forebrain }\end{array}$ & & \\
\hline & & $\begin{array}{l}\text { Thalamus } \\
\text { Forebrain }\end{array}$ & & \\
\hline \multirow[t]{5}{*}{$\begin{array}{l}\text { Relapse (negative } \\
\text { reinforcement; } \\
\text { stress-induced } \\
\text { craving) }\end{array}$} & $\begin{array}{l}\text { Positive } \\
\text { reinforcement } \\
\text { for survival }\end{array}$ & $\begin{array}{c}\text { Ventral Tegmental Area } \\
\text { Midbrain }\end{array}$ & $\begin{array}{r}\text { Positive } \\
\text { reinforcement for } \\
\text { survival }\end{array}$ & $\begin{array}{r}\text { Negative } \\
\text { reinforcement } \\
\text { (numb-out emotions) }\end{array}$ \\
\hline & & Nucleus Incertus & & \\
\hline & & $\begin{array}{l}\text { Pituitary Gland } \\
\text { Brain-Base }\end{array}$ & $\begin{array}{r}\text { Regulate } \\
\text { endocrine } \\
\text { system } \\
\end{array}$ & \\
\hline & & Blood-Brain-Barrier & & \\
\hline & & $\begin{array}{l}\text { Autonomic Nervous } \\
\text { System }\end{array}$ & & \\
\hline Hyper-/Hypo-CORT & & Adrenal Cortex & $\begin{array}{r}\text { Mobilize substrates } \\
\text { needed } \\
\text { by the body during } \\
\text { stress }\end{array}$ & $\begin{array}{r}\text { Hyper-I } \\
\text { Hypo-CORT }\end{array}$ \\
\hline
\end{tabular}

Fig. 2. Addiction and toxic stress pathways. Copyright (C) Susie Wiet, MD 2016. CORT: cotisol, CNS: central nervous system, ANS: autonmic nervous system. 
The circuitry implicated in addiction are perturbations of the RewP that are embedded in subcortical structures of the medial forebrain bundle spanning the ventral forebrain and ventral midbrain. ${ }^{42)}$ The disease state of addiction arises from damage to and/or dysregulation of the RewP, resulting in maladaptive learning ${ }^{28,43,44)}$ and compromised health that can lead to early death (not unlike that associated with ACEStudy scores). In rat models, chronic administration of addictive substances results in activation of the RewP, which also produces changes in the RegP that are congruent with the effects of CT. This is not surprising, given that both pathways share the same neuroanatomical structures and some overlapping associations during homeostasis (Fig. 2). Symptoms associated with addiction that arise from dysregulated areas of the RewP include: 1 ) repetitive seeking (ventral pallidum $\left.^{45}\right)$, 2) impulsivity (PFC), 3) mood instability and emotional reactivity (VTA-NAcc-EAm), 4) pain sensitivity (NAcc), and 5) somatic complaints (HPA reset point $\left.{ }^{44}\right)$. Controllable stress can enhance learning for females (vs males) and is associated with cognitive resilience; conversely, males (vs females) tend to manage adverse stress more readily, making them more emotionally resilient. ${ }^{46)}$

CT (and other major stressors) induces substantial release of POMC from the HYP, which simultaneously induces excessive secretion of ACTH and $\beta$-END. ${ }^{47)}$ The latter stimulates the VTA (densely rich in opioid receptors) and induces the RewP, which simultaneously reinforces activation in the $\mathrm{EAm},{ }^{48)}$ causing a loop effect of reinforcement (remaining in the midbrain-forebrain-temporal lobe) of emotional memory and dissociates conscious memory from behavior and emotions (e.g. conscious awareness is likely no longer integrated, which is observed clinically). Such internal experiences coupled with a desire to escape from the 'unthinkable' sets up a neurobiological invitation to addictive substances and behaviors. These actions flood the VTA-NAcc pathway and provide temporary relief through endogenous opioid reinforcement but at the expense of additional dysregulation ${ }^{49)}$ and further dissociation from conscious awareness of the 'unthinkable.' Clinically, dysregulation in both pathways synergistically contribute to symptoms prevalent in traumatic stress disorders.

More recently, POMC has been identified as playing a significant role in addiction. However, POMC is not typically secreted as part of the RewP, from which addiction arises. Substantial and chronic release of POMC seemingly primes the RewP likely by the effect of END stimulation of the VTA, which causes disinhibition of DA release and hyper-polarizes DA receptors (DAR) within the LS, including the EAm. $\beta$-END release (from POMC-induced CRH) affects the 1) ascending pathway (mesolimbic, DA dominance) and is im- plicated in craving an addictive substance ${ }^{50,51)}$;2) descending pathway (opioid dominance): producing intoxication ${ }^{29)}$; 3) further-ascending (GABA and GLU dominance): resulting in reinforcement of behavior ${ }^{52,53)}$; and 4) interneuron (VTA, opioid dominant): changing to negative reinforcement in addiction. ${ }^{54)}$

Addictive substances stimulate the same s-NAcc structure but release excessive DA, which results in hyperpolarization of the DAR. Repetitive stimulation leads to decreased sensitization of the DAR, likely due to DYN-another key endogenous opioid binding and modulating DAR function. When dysregulated by addiction, behavior is overly reinforced and results in compulsively focused motivation to achieve the same s-NAcc release ${ }^{43}$; however, that same level of stimulation is never again achieved despite the compulsivity of desire that results to experience it again. The pursuit becomes a fixated, semi-conscious compulsion coupled with dysphoria (hedonic tone) when the receptors of the VTA, s-NAcc, EAm are not saturated. Indeed, well accepted triggers for relapse include: 1) familiarity of situation, 2) availability of/access to addictive substance, 3 ) distress (extremes of positive and negative emotions), and perhaps 4) psychiatric instability-all triggers that are mediated by dysfunctional neurobiology.

In severe emotional dysregulation from CT (without exposure to addictive substances), a similar behavioral pattern to addiction and relapse can arise that is analogous to a psychodynamic term, repetition compulsion (RC). This maladaptive behavior pattern is emotionally-driven but unconscious. $\mathrm{RC}$ is typically stimulated by intense emotion, distress, contextual cues (e.g. location, time of year, etc.), or situation familiarity that induces unconscious reengagement of traumatic-like experiences. For example, a person who has experienced severe CT and has vowed to have a better life enters into revolving relationships that are demeaning and abusive but cannot seem to disengage from the repetitious cycle. To the outsider, the neurobiological pathology of the RegP is not visible, but the resulting maladaptive behavior is often interpreted as a form of addiction (e.g. "they are addicted to bad relationships"). Intensive trauma-resolution therapy can be life-saving and assists with reuniting the LSHPA with conscious awareness (disallowing compulsive, unconscious behavior).

Similarly, other behavioral addictions (including food, pornography, sex, etc.) share similar neurobiological pathology that results in a pattern of abnormal behavior that is cued by the same challenges of relapse: distress (intense emotion), contextual cues, and familiar 'drug' of choice present. Related behavioral addictions implicate neuroendocrine cascades involving the $\mathrm{THAL}^{32)}$ and that arise from dysregulation of the RewP and RegP pathways. 


\section{Overlapping pathways and ligands}

Upregulation of POMC and PRODYN in the arc nucleus of the HYP from CT due to chronic $\mathrm{CRH}$ stimulation alters neurocircuitry, brain structures and neuroanatomical function. ${ }^{40)}$ These widespread changes implicate dysregulation of cognitive, emotional, behavioral, and physical health.

POMC concentration plays pivotal roles during all stages of life, beginning with embryonic life. ${ }^{18)}$ It can promote neurogenesis when balanced and can wreak havoc when overly stimulated by CRH. POMC naturally decreases with aging and/or exercise. It is inhibited during acute withdrawal but during long-term withdrawal it remains increased. ${ }^{55)}$ This may be suggestive of a survival mechanism or preparedness to manage anticipated stress and assist with immune function through the opioid cascade.

Additional POMC circuitry includes stimulation from the EAm, which in normal states is involved in 1) induced fear conditioning, 2) anxiety-related awareness, 3) stress response, 4) social processing, 5) sexual-behavior regulation, and 6) social-situation recognition. ${ }^{56)}$ In aberrant stressful conditions, POMC can upregulate intracellular c-Fos expression (via induction of transcription), such as from HPA and/or acute withdrawal stimulation. Such effects of POMC dysregulation of the HYP is implicated in: 1) increased eating, 2) increased respiration, 3) limbic excitation, 4) pain perception, 5) analgesia, 6) addiction, 7) sexual behavior, 8) learning/ memory, 9) cardiovascular homeostasis, and 10) hypophyseal hormone secretion. ${ }^{56)}$ In the RegP, POMC cleaves to produce $\beta$-END, which has direct action at mu-opioid receptors and modulatory action at N-methyl-D-aspartate (NMDA) receptors throughout the RegP (Table 2).

In contrast to $\beta$-END, DYN decreases DA release due to binding at the kappa-DAR ( $\varkappa$-DAR) with predominant effect in the NAcc and D-STR. Dynorphin is derived from the prohormone, prodynorphin (PDYN). PDYN co-releases with ACTH (anterior pituitary) and CRH (HYP) via $x$-DAR. Dynorphins are involved in modulating the Rewp, processing pain, ${ }^{57)}$ and memory acquisition. Interestingly, DYNs are at highest concentration in the AMY, HIPP, STR, and presentbut less so-in PFC, ${ }^{58)}$ which are the predominant structures of the RegP, although the STR is implicated more in the RewP. Dynorphin also modulates NMDA receptors function in the HYP, ${ }^{24)}$ similar to $\beta$-END (Table 2).

Dynorphin is present during fetal neurodevelopment and also stimulates release of CRH and AVP from the HYP via kappa-opioid receptors throughout life, indicating a role with inflammation. Dynorphin also plays a brief non-opioid peripartum role in regulating stress/homeostasis via regulation of prostaglandins that extinguishes shortly after birth. ${ }^{24)}$ Perhaps this evolved to prepare offspring for survival by advancing pulmonary development and as protection from the profound maternal-fetal metabolic shifts implicated during birth. The implications of maternal distress, analogous to effects of CT, causing altered expression and function of DYN on fetal development are serious and pose risk for spontaneous abortion, low birthweight, and altered neurodevelopment in offspring. ${ }^{59,60)}$ Indeed, decreased dendritic arborization and GLU density in the PFC and HIPP is implicated, while in-

Table 2. Basic opioid function in the reward and regulation pathways

\begin{tabular}{|c|c|c|c|}
\hline Opioid & Storage & Stress & Addiction \\
\hline Dynorphin & $\begin{array}{l}\text { - Hypothalamus } \\
\text { - Striatum } \\
\text { - Hippocampus } \\
\text { - Spinal cord }\end{array}$ & $\begin{array}{l}\text { - Corticotropin-releasing hormone } \\
\text { stimulates dynorphin } \\
\text { - Corticotropin-releasing hormone } \\
\text { increases expression of prodynorphin } \\
\text { in the hippocampus and nucleus } \\
\text { accumbens and blocks glutamate- } \\
\text { decreases learning } \\
\text { - Kappa antagonists increase resiliency } \\
\text { to stress }\end{array}$ & $\begin{array}{l}\text { - Decreased dopamine release due } \\
\text { to binding of DYN at the dopamine } \\
\text { receptors (especially nucleus } \\
\text { accumbens and dorsal striatum) } \\
\text { - Kappa stimulation induces } \\
\text { stress-related craving }\end{array}$ \\
\hline Beta-endorphin & $\begin{array}{l}\text { - Pituitary (released to } \\
\text { blood/periphery) } \\
\text { - Hypothalamus } \\
\text { (extended amygdala, } \\
\text { mesencephalic } \\
\text { reticular formation, } \\
\text { periaqueductal gray } \\
\text { matter, rostral ventral } \\
\text { medulla) }\end{array}$ & $\begin{array}{l}\text { - Corticotropin-releasing hormone binds } \\
\text { presynaptic corticotropin-releasing } \\
\text { hormone and mu-opioid receptors that } \\
\text { inhibit GABA release, which causes } \\
\text { excess release of dopamine } \\
\text { - Corticotropin-releasing hormone and } \\
\text { pro-inflammatory cytokine bind } \\
\text { lymphocytes and stimulates beta- } \\
\text { endorphin during inflammation }\end{array}$ & $\begin{array}{l}\text { - Increased corticotropin-releasing } \\
\text { hormone receptors } \\
\text { - Increased corticotropin-releasing } \\
\text { hormone release }\end{array}$ \\
\hline
\end{tabular}

DYN: dynorphin 
crease of NAcc neuroadaptation suggests loss of inhibitory control and decreased learning. ${ }^{61)}$

Collectively, the endogenous opioids have neuromodulatory effects at the pre and post-synaptic stimulatory NMDA receptors, which reside throughout in the RewP and RegP structures on glutamatergic neurons located most predominantly in the HIPP, THAL, STR, and cerebral cortex. ${ }^{62)}$ Normal stimulation of the NMDA receptor provides a mechanism for embedding memory and learning, perhaps by reinforcing the probability of repeating a behavior via interneuron stimulation in the VTA. Dysregulation in either of these pathways leads to challenges in encoding memory and learning.

Several neuropeptides are implicated in altered pathways due to dysregulation of endogenous opioid and CORT systems associated with addiction and/or CT. Neuro-Y peptide (NYP) is a prime example. NYP storage is ubiquitous throughout the cortex, AMY, HYP, and locus coeruleus and is predominantly co-located with DYN. NYP receptors are localized on or impact the function of neighboring neurons expressing GABA, GLU, CRH, and NE. ${ }^{63)}$ This redundant mechanism gives rise to various and altered behaviors involving feeding, novelty-seeking, and cognitive function, as well as emotional regulation. A primary mechanism of central NYP is implicated in feeding behavior; and excessive stimulation of CORT in the arcuate nucleus creates a 'vicious circle' of additional NYP release that is implicated in biophysiologic changes consistent with metabolic syndrome. ${ }^{64)}$ Although food stimulates both peripheral and central pathways, perhaps the imbalanced mechanism involved in food addictions implicates not only NYP but also DYN ${ }^{21,65)}$ and is regulated by stress. Food (particularly carbohydrate-fat) is commonly known to be a replacement addiction for illicit substances and a standalone addiction associated with CT that leads to obesity, and which is clinically reported as a vehicle to control or avoid emotions.

An additional neuropeptide that deserves mention is relaxin-3 (RXFP3), which is implicated in signaling arousal, feeding, stress responses, and cognition. ${ }^{66)}$ This is a recently discovered system that projects from the nucleus incertus (NucI). Although this nucleus was originally known as the 'nucleus of uncertain function,' it seems to be highly implicated in simultaneously stimulating both the RewP and RegP. The NucI is located in the hindbrain (midline prepontine area), which suggests a primitive role in stress modulation and behavioral adaptation. Indeed, projections are ubiquitous throughout the combined structures implicated in the RewP and RegP pathways. Importantly, the NucI has regulatory input for all structures implicated in the RewP and RegP through two mechanisms: 1) HYP-neuroendocrine modulation (stimulation of oxytocin, AVP, and CRH release) and 2) HIPP-electrical activity (theta-wave stimulation) that regulates acute-stress-stimulus related behavior ${ }^{67)}$ through GABA activity. The latter also activates c-Fos expression within limbic structures, $\left.{ }^{68}\right)$ implicating stress regulation and is associated with relapse in rat models through HIPP thetawave stimulation of the AMY and entorhinal cortex. ${ }^{53)}$ In humans, this translates into a powerful pathway of emotional-memory-induced relapse, which may be the mechanism for that which is clinically observed in normal conditions of the RegP and RewP, and which is magnified in respective LS-HPA dysregulation and addiction.

Interestingly, RXFP3 is stimulated by $\mathrm{CRH}$ in stress, relapse (activation of the BNST, which is part of the EAm), as well as feeding behavior. ${ }^{69)}$ Also of interest is that DAR-2 receptors reside in the $\mathrm{NI}^{70)}$ and interface with serotonin (5-HT) neurons in the raphe nucleus and NE neurons in the locus coeruleus, ${ }^{71)}$ which may give rise to related psychopathology. Perhaps the NucI is a primary stimulus for dysregulation of the RewP and RegP pathways that may prove to contain future keys for central treatment over these complex systems.

\section{COMMENTARY}

The RewP and RegP are highly integrated and share current-time activity through the same structures and are an extremely complex mixture of ligands and trajectories causing broad downstream effects. As one pathway is overloaded from chronic exposure to addictive substances (including behavior) or extreme stress, the other pathway will also become overloaded causing cumulative dysregulation in emotional, behavioral and cognitive domains that cause downstream effect on the ANS and epigenetic translation and intergenerational transfer due to dysregulation of these life-supporting systems. ${ }^{72}$

An important question remains as to how intervention and treatment can repair and/or restore the aberrant pathways to normal functioning. Perhaps lessons can be learned from observing patients who are in active and long-term recovery from both $\mathrm{CT}$ and addiction, and have seemingly improved the function of RewP and RegP pathways. Perhaps the simultaneous interface of addressing emotional dysregulation, while addressing cravings, and reworking behavior responses allow for improved normalization of these pathways that lead to building resiliency skills. The core feature of healing these pathways is based on raising conscious awareness to 1) emotional triggers and cravings, 2) irrational thoughts, 3) current behavior choices (in present-time), and 4) the new and successful behavior that had previously been averted from conscious awareness secondary to neurobiological changes. The psychodynamic interpretation as such, is that 
this process creates a corrective emotional experience, which begins to improve function of the RegP and with repetition, will improve function of the RewP.

Simultaneous healing of these pathways is akin to the emotional regulation and rewarding guidance that effective parents provide to their children. External recognition and celebration of the small steps of emotional regulation encourages willingness to tackle increasingly more advanced steps in recovery and promotes normalization of the RegP and RewP. Although long-term potentiation for relapse remains due to the history of pathway dysregulation, the potential for relapse can be mitigated greatly by raising conscious awareness about the perturbations of these pathways. Conscious awareness of emotions and thoughts can lead to effective behavior choices, which supports the importance of mind-body healing through restoration of the RewP and RegP.

\section{Conflicts of Interest}

The author has no financial conflicts of interest.

\section{REFERENCES}

1) American Society of Addiction Medicine. Public policy statement: short definition of addiction. [cited 2011 Dec 4]. Available from: http://www.asam.org/quality-practice/definition-of-addiction.

2) Sapolsky RM. Stress, glucocorticoids, and damage to the nervous system: the current state of confusion. Stress 1996;1:1-19.

3) Qin D, Patel SM, Champion HC. "Happiness" and stress cardiomyopathy (apical ballooning syndrome/takotsubo syndrome). Int J Cardiol 2014;172:e182-e183.

4) Schleifer SJ, Macari-Hinson MM, Coyle DA, Slater WR, Kahn M, Gorlin R, et al. The nature and course of depression following myocardial infarction. Arch Intern Med 1989;149:1785-1789.

5) Felitti VJ, Anda RF, Nordenberg D, Williamson DF, Spitz AM, Edwards V, et al. Relationship of childhood abuse and household dysfunction to many of the leading causes of death in adults. The adverse childhood experiences (ACE) Study. Am J Prev Med 1998;14:245-258.

6) Dube SR, Felitti VJ, Dong M, Chapman DP, Giles WH, Anda RF. Childhood abuse, neglect, and household dysfunction and the risk of illicit drug use: the adverse childhood experiences study. Pediatrics 2003;111:564-572.

7) Dube SR, Felitti VJ, Dong M, Giles WH, Anda RF. The impact of adverse childhood experiences on health problems: evidence from four birth cohorts dating back to 1900. Prev Med 2003;37:268-277.

8) Dong M, Giles WH, Felitti VJ, Dube SR, Williams JE, Chapman DP, et al. Insights into causal pathways for ischemic heart disease: adverse childhood experiences study. Circulation 2004;110:17611766.

9) Huang H, Yan P, Shan Z, Chen S, Li M, Luo C, et al. Adverse childhood experiences and risk of type 2 diabetes: a systematic review and meta-analysis. Metabolism 2015;64:1408-1418.

10) Fuemmeler BF, Dedert E, McClernon FJ, Beckham JC. Adverse childhood events are associated with obesity and disordered eating: results from a U.S. population-based survey of young adults. J Trauma Stress 2009;22:329-333.

11) Brown MJ, Thacker LR, Cohen SA. Association between adverse childhood experiences and diagnosis of cancer. PLoS One 2013;8: e65524.

12) Chapman DP, Whitfield CL, Felitti VJ, Dube SR, Edwards VJ,
Anda RF. Adverse childhood experiences and the risk of depressive disorders in adulthood. J Affect Disord 2004;82:217-225.

13) Heim $C$, Nemeroff $C B$. The role of childhood trauma in the neurobiology of mood and anxiety disorders: preclinical and clinical studies. Biol Psychiatry 2001;49:1023-1039.

14) Wu NS, Schairer LC, Dellor E, Grella C. Childhood trauma and health outcomes in adults with comorbid substance abuse and mental health disorders. Addict Behav 2010;35:68-71.

15) Dube SR, Fairweather D, Pearson WS, Felitti VJ, Anda RF, Croft JB. Cumulative childhood stress and autoimmune diseases in adults. Psychosom Med 2009;71:243-250.

16) Friedman H, Eisenstein TK. Neurological basis of drug dependence and its effects on the immune system. J Neuroimmunol 2004;147: 106-108.

17) Saper CB, Lowell BB. The hypothalamus. Curr Biol 2014;24:R1111R1116.

18) Padilla SL, Reef D, Zeltser LM. Defining POMC neurons using transgenic reagents: impact of transient Pomc expression in diverse immature neuronal populations. Endocrinology 2012;153:1219-1231.

19) Sprouse-Blum AS, Smith G, Sugai D, Parsa FD. Understanding endorphins and their importance in pain management. Hawaii Med J 2010;69:70-71.

20) Schäfer M, Carter L, Stein C. Interleukin 1 beta and corticotropinreleasing factor inhibit pain by releasing opioids from immune cells in inflamed tissue. Proc Natl Acad Sci U S A 1994:91:4219-4223.

21) Welch CC, Kim EM, Grace MK, Billington CJ, Levine AS. Palatability-induced hyperphagia increases hypothalamic dynorphin peptide and mRNA levels. Brain Res 1996;721:126-131.

22) Wersinger SR, Caldwell HK, Martinez L, Gold P, Hu SB, Young WS 3rd. Vasopressin 1a receptor knockout mice have a subtle olfactory deficit but normal aggression. Genes Brain Behav 2007;6:540-551.

23) Bremne JD, Vermetten E. Stress and development: behavioral and biological consequences. Dev Psychopathol 2001;13:473-489.

24) Szeto HH. Dynorphin and the hypothalamo-pituitary-adrenal axis during fetal development. Life Sci 2003;73:749-758.

25) Tsigos C, Chrousos GP. Hypothalamic-pituitary-adrenal axis, neuroendocrine factors and stress. J Psychosom Res 2002;53:865-871.

26) Tomkins DM, Sellers EM. Addiction and the brain: the role of neurotransmitters in the cause and treatment of drug dependence. CMAJ 2001;164:817-821.

27) Segerstrom SC, Miller GE. Psychological stress and the human immune system: a meta-analytic study of 30 years of inquiry. Psychol Bull 2004;130:601-630.

28) Nestler EJ. Is there a common molecular pathway for addiction? Nat Neurosci 2005;8:1445-1449.

29) Koob GF, Volkow ND. Neurocircuitry of addiction. Neuropsychopharmacology 2010;35:217-238.

30) Jennings JH, Sparta DR, Stamatakis AM, Ung RL, Pleil KE, Kash TL, et al. Distinct extended amygdala circuits for divergent motivational states. Nature 2013;496:224-228.

31) Franklin TR, Wang Z, Wang J, Sciortino N, Harper D, Li Y, et al. Limbic activation to cigarette smoking cues independent of nicotine withdrawal: a perfusion fMRI study. Neuropsychopharmacology 2007;32:2301-2309.

32) Kelley AE, Baldo BA, Pratt WE. A proposed hypothalamic-thalamic-striatal axis for the integration of energy balance, arousal, and food reward. J Comp Neurol 2005;493:72-85.

33) Ford JD, Kidd P. Early childhood trauma and disorders of extreme stress as predictors of treatment outcome with chronic posttraumatic stress disorder. J Trauma Stress 1998;11:743-761.

34) Triffleman EG, Marmar CR, Delucchi KL, Ronfeldt H. Childhood trauma and posttraumatic stress disorder in substance abuse inpatients. J Nerv Ment Dis 1995;183:172-176.

35) Bremner JD, Southwick SM, Johnson DR, Yehuda R, Charney DS. Childhood physical abuse and combat-related posttraumatic stress 
disorder in Vietnam veterans. Am J Psychiatry 1993;150:235-239.

36) Saxon AJ, Davis TM, Sloan KL, McKnight KM, McFall ME, Kivlahan DR. Trauma, symptoms of posttraumatic stress disorder, and associated problems among incarcerated veterans. Psychiatr Serv 2001;52:959-964

37) Heffernan K, Cloitre M, Tardiff K, Marzuk PM, Portera L, Leon AC. Childhood trauma as a correlate of lifetime opiate use in psychiatric patients. Addict Behav 2000;25:797-803.

38) Koob GF. A role for brain stress systems in addiction. Neuron 2008; 59:11-34.

39) Ivy AS, Rex CS, Chen Y, Dubé C, Maras PM, Grigoriadis DE, et al. Hippocampal dysfunction and cognitive impairments provoked by chronic early-life stress involve excessive activation of CRH receptors. J Neurosci 2010;30:13005-13015.

40) Chen P, Vaughan J, Donaldson C, Vale W, Li C. Injection of urocortin 3 into the ventromedial hypothalamus modulates feeding, blood glucose levels, and hypothalamic POMC gene expression but not the HPA axis. Am J Physiol Endocrinol Metab 2010;298:E337E345.

41) McGowan PO. Epigenomic mechanisms of early adversity and HPA dysfunction: considerations for PTSD research. Front Psychiatry 2013;4:110

42) Sousa N, Lukoyanov NV, Madeira MD, Almeida OF, Paula-Barbosa MM. Reorganization of the morphology of hippocampal neurites and synapses after stress-induced damage correlates with behavioral improvement. Neuroscience 2000;97:253-266.

43) Di Chiara G, Bassareo V, Fenu S, De Luca MA, Spina L, Cadoni C, et al. Dopamine and drug addiction: the nucleus accumbens shell connection. Neuropharmacology 2004;47 Suppl 1:227-241.

44) Koob GF, Le Moal M. Drug addiction, dysregulation of reward, and allostasis. Neuropsychopharmacology 2001;24:97-129.

45) Erb S, Shaham Y, Stewart J. Stress reinstates cocaine-seeking behavior after prolonged extinction and a drug-free period. Psychopharmacology (Berl) 1996;128:408-412.

46) DeSantis SM, Baker NL, Back SE, Spratt E, Ciolino JD, MoranSanta Maria M, et al. Gender differences in the effect of early life trauma on hypothalamic-pituitary-adrenal axis functioning. Depress Anxiety 2011;28:383-392.

47) Rousseau K, Kauser S, Pritchard LE, Warhurst A, Oliver RL, Slominski A, et al. Proopiomelanocortin (POMC), the ACTH/melanocortin precursor, is secreted by human epidermal keratinocytes and melanocytes and stimulates melanogenesis. FASEB J 2007;21: 1844-1856

48) Polter AM, Kauer JA. Stress and VTA synapses: implications for addiction and depression. Eur J Neurosci 2014;39:1179-1188.

49) Dunbar JC, Lu H. Proopiomelanocortin (POMC) products in the central regulation of sympathetic and cardiovascular dynamics: studies on melanocortin and opioid interactions. Peptides 2000;21: 211-217.

50) Heinz A, Siessmeier T, Wrase J, Hermann D, Klein S, Grüsser SM, et al. Correlation between dopamine $\mathrm{D}(2)$ receptors in the ventral striatum and central processing of alcohol cues and craving. Am J Psychiatry 2004;161:1783-1789.

51) Berridge KC. The debate over dopamine's role in reward: the case for incentive salience. Psychopharmacology (Berl) 2007;191:391-431.

52) Sanchis-Segura C, Spanagel R. Behavioural assessment of drug reinforcement and addictive features in rodents: an overview. Addict Biol 2006;11:2-38.

53) Vorel SR, Liu X, Hayes RJ, Spector JA, Gardner EL. Relapse to cocaine-seeking after hippocampal theta burst stimulation. Science 2001;292:1175-1178

54) Sinha R, Fuse T, Aubin LR, O’Malley SS. Psychological stress, drug- related cues and cocaine craving. Psychopharmacology (Berl) 2000;152:140-148.

55) Vinson GP, Brennan CH. Addiction and the adrenal cortex. Endocr Connect 2013;2:R1-R14.

56) Niikura K, Zhou Y, Ho A, Kreek MJ. Proopiomelanocortin (POMC) expression and conditioned place aversion during protracted withdrawal from chronic intermittent escalating-dose heroin in POMCEGFP promoter transgenic mice. Neuroscience 2013;236:220-232.

57) Jamero D, Borghol A, Vo N, Hawawini F. The emerging role of NMDA antagonists in pain management. US Pharm 2011;36: HS4HS8.

58) Marinova Z. Opioid and non-opioid activities of the dynorphins [dissertation]. Stockholm, Karolinska institutet;2006.

59) Shah PS, Shah J; Knowledge Synthesis Group on Determinants of Preterm/LBW Births. Maternal exposure to domestic violence and pregnancy and birth outcomes: a systematic review and metaanalyses. J Womens Health (Larchmt) 2010;19:2017-2031.

60) Radtke KM, Ruf M, Gunter HM, Dohrmann K, Schauer M, Meyer A, et al. Transgenerational impact of intimate partner violence on methylation in the promoter of the glucocorticoid receptor. Transl Psychiatry 2011;1:e21.

61) Russo SJ, Murrough JW, Han MH, Charney DS, Nestler EJ. Neurobiology of resilience. Nat Neurosci. 2012;15:1475-1484.

62) Mao J. NMDA and opioid receptors: their interactions in antinociception, tolerance and neuroplasticity. Brain Res Brain Res Rev 1999;30:289-304

63) Pleil KE, Rinker JA, Lowery-Gionta EG, Mazzone CM, McCall NM, Kendra AM, et al. NPY signaling inhibits extended amygdala CRF neurons to suppress binge alcohol drinking. Nat Neurosci 2015;18:545552.

64) Kakui N, Kitamura K. Direct evidence that stimulation of neuropeptide Y Y5 receptor activates hypothalamo-pituitary-adrenal axis in conscious rats via both corticotropin-releasing factor- and arginine vasopressin-dependent pathway. Endocrinology 2007;148:28542862 .

65) Lin S, Boey D, Lee N, Schwarzer C, Sainsbury A, Herzog H. Distribution of prodynorphin mRNA and its interaction with the NPY system in the mouse brain. Neuropeptides 2006;40:115-123.

66) Ganella DE, Ma S, Gundlach AL. Relaxin-3/RXFP3 signaling and neuroendocrine function - a perspective on extrinsic hypothalamic control. Front Endocrinol (Lausanne) 2013;4:128

67) Seidenbecher T, Laxmi TR, Stork O, Pape HC. Amygdalar and hippocampal theta rhythm synchronization during fear memory retrieval. Science 2003;301:846-850.

68) Ryan PJ, Ma S, Olucha-Bordonau FE, Gundlach AL. Nucleus incertus--an emerging modulatory role in arousal, stress and memory. Neurosci Biobehav Rev 2011 May;35:1326-1341.

69) Walker LC, Kastman HE, Koeleman JA, Smith CM, Perry CJ, Krstew EV, et al. Nucleus incertus corticotrophin-releasing factor 1 receptor signalling regulates alcohol seeking in rats. Addict Biol $2016 \mathrm{Jul} 20$ [Epub ahead of print]. http://dx.doi.org/10.1111/adb.12426.

70) Kumar JR, Rajkumar R, Farooq U, Lee LC, Tan FC, Dawe GS. Evidence of $\mathrm{D} 2$ receptor expression in the nucleus incertus of the rat. Physiol Behav 2015;151:525-534.

71) Haidar M, Lam M, Chua BE, Smith CM, Gundlach AL. Sensitivity to chronic methamphetamine administration and withdrawal in mice with relaxin-3/RXFP3 Deficiency. Neurochem Res 2016; 41:481-491.

72) Yehuda R, Daskalakis NP, Lehrner A, Desarnaud F, Bader HN, Makotkine I, et al. Influences of maternal and paternal PTSD on epigenetic regulation of the glucocorticoid receptor gene in Holocaust survivor offspring. Am J Psychiatry 2014;171:872-880. 